Prepared for the U.S. Department of Energy under Contract DE-AC05-76RL01830

\title{
A Brief Analysis of Geologic CO2 Storage Potential in South Korea
}

JJ Dooley

June 2006

Pacific Northwest

NATIONAL LABORATORY 


\title{
DISCLAIMER
}

This report was prepared as an account of work sponsored by an agency of the United States Government. Neither the United States Government nor any agency thereof, nor Battelle Memorial Institute, nor any of their employees, makes any warranty, express or implied, or assumes any legal liability or responsibility for the accuracy, completeness, or usefulness of any information, apparatus, product, or process disclosed, or represents that its use would not infringe privately owned rights. Reference herein to any specific commercial product, process, or service by trade name, trademark, manufacturer, or otherwise does not necessarily constitute or imply its endorsement, recommendation, or favoring by the United States Government or any agency thereof, or Battelle Memorial Institute. The views and opinions of authors expressed herein do not necessarily state or reflect those of the United States Government or any agency thereof.

\author{
PACIFIC NORTHWEST NATIONAL LABORATORY \\ operated by \\ BATTELLE \\ for the \\ UNITED STATES DEPARTMENT OF ENERGY \\ under Contract DE-AC05-76RL01830
}

Printed in the United States of America
Available to DOE and DOE contractors from the Office of Scientific and Technical Information,
P.O. Box 62, Oak Ridge, TN 37831-0062;
ph: (865) 576-8401
fax: $(865)$ 576-5728
email: reports@adonis.osti.gov

\begin{abstract}
Available to the public from the National Technical Information Service, U.S. Department of Commerce, 5285 Port Royal Rd., Springfield, VA 22161 ph: (800) 553-6847 fax: $(703) 605-6900$ email: orders@ntis.fedworld.gov online ordering: http://www.ntis.gov/ordering.htm
\end{abstract}

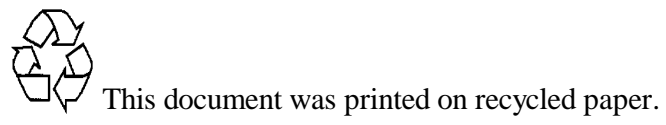




\section{A Brief Analysis of Geologic $\mathrm{CO}_{2}$ Storage Potential in South Korea JJ Dooley, Joint Global Change Research Institute \\ June 27, 2006 \\ PNNL-15895}

Question: Does South Korea have much geologic $\mathrm{CO}_{2}$ storage potential?

\section{Answer:}

- There is relatively little published literature that directly and rigorously attempts to quantify the geologic storage potential in and around South Korea.

- The literature that does exists suggest that $\mathrm{CO}_{2}$ storage potential in South Korea is potentially small and of lower quality / more expensive to utilize as the majority of the storage potential lies in offshore deep saline reservoirs.

- Even nations that do not have substantial $\mathrm{CO}_{2}$ storage resources can benefit from CCS technologies through the purchase of lower-cost emissions credits made possible by CCS use in other nations.

- Countries such as Korea will likely see their future use of fossil-energy technologies and therefore the mix of energy technologies they can use - more constrained under future greenhouse gas policies than if they had more onshore geologic $\mathrm{CO}_{2}$ storage capacity than they are currently thought to possess.

\section{Supporting Material}

In a recently released report from the Australian CO2CRC that was carried out for APEC, the authors note that "The Republic of Korea and Chinese Taipei both have high emissions $\left(10^{2} \mathrm{MtCO}_{2} / \mathrm{y}\right)$ and low storage prospectivity (i.e., low storage potential). Both have limited sedimentary basins within their boundaries, and consequently little options for saline reservoir, hydrocarbon field or coal bed storage."

Citation: Ian Newlands, et. al. "Assessing the $\mathrm{CO}_{2}$ Storage Prospectivity of Developing Economies in APEC - Applying methodologies developed in GEODISC to Selected Sedimentary Basins in the Eastern Asian Region." Presented at The Eighth International Conference on Greenhouse Gas Control Technologies. June 2006. https://events.adm.ntnu.no/ei/viewpdf.esp?id=24\&file=d\%3A\%5CAmlink\%5CE VENTWIN\%5Cdocs\%5Cpdf\%5C950Final00313\%2Epdf

The Newlands GHGT8 paper is a summary of a longer report prepared for APEC by $\mathrm{CO} 2 \mathrm{CRC}$ and released in June of 2005. Page 56 of this longer technical report provides a qualitative description of the candidate storage formations in and around South Korea. The report does not provide a quantitative estimate of potential storage capacity, but does reaffirm the principal conclusion of the quote above that South Korea's geologic $\mathrm{CO}_{2}$ storage potential is probably quite small and of relatively low quality. This more detailed technical report can be found at: 
http://www.co2crc.com.au/PUBFILES/STOR0405/APEC/APEC_Phase1_FinalR eport.pdf

As a part of the Battelle-led Global Energy Technology Strategy Project, in 2004, we carried out a detailed survey of the literature on geologic storage potentials for various regions of the world. While we found no published literature that spoke directly to South Korea's geologic storage potential, the literature that was available allowed us to draw the following conclusions:

- There is relatively small $\mathrm{CO}_{2}$ storage capacity potential within South Korean coal seams.

- There is effectively no $\mathrm{CO}_{2}$ storage capacity in South Korean depleted oil and gas fields

- $\mathrm{CO}_{2}$ storage potential in on-shore deep saline formations is very limited.

- We estimated that there could be a total of $0.4 \mathrm{GtCO}_{2}$ storage capacity in offshore deep saline aquifers for Korea but that these would be relatively more expensive to utilize.

Citation: JJ Dooley and SJ Friedman. "A Regionally Disaggregated Global Accounting of $\mathrm{CO}_{2}$ Storage Capacity: Data and Assumptions." Joint Global Change Research Institute, Battelle Pacific Northwest Division. PNWD-3431. May 2004. College Park, MD.

The more recent work from the Australian CO2CRC appears to agree that to the extent there is geologic $\mathrm{CO}_{2}$ storage potential in Korea it likely lies in offshore deep saline formations. 